\title{
A post-colonial legal approach to the Chagos case and the (dis)application of land rights norms
}

\author{
Kinnari Bhatt* \\ English qualified solicitor, post-doctoral researcher at Erasmus School of Law and the International Institute of Social Studies, \\ Erasmus University Rotterdam, and Visiting Fellow at the Transnational Law Institute, Dickson Poon School of Law, Kings \\ College London \\ ${ }^{\star}$ Corresponding author. E-mail: kinnari@bhattsolicitor.info
}

\begin{abstract}
One way of understanding the exile of the Chagos Islanders and their inability to return to their ancestral land is through a reading of the case from a perspective of post-colonial legal scholarship. Chagossians have strong legal rights to land and remedies of compensation and return through a purposive application of the international legal definition of Indigenous, Magna Carta right to abode and international human rights law that could address their dispossession. Yet, the inability of those rights to be meaningfully applied has been constrained because of the post-colonial way they are legally interpreted, creating a legal vacuum in which basic fairness and substantive equality have been routinely compromised. Drawing attention to the continued legal denial of return in the context of decolonisation, ongoing colonialism and the rule of law makes sense of the legal record and explains the expulsion of the islanders despite the moral merits of return.
\end{abstract}

Keywords: Chagos, land rights, indigenous, post-colonial, access to justice

\section{Introduction}

How are we to understand the decades-long exile of the Chagos Islanders from their ancestral land? What bearing on the islanders' ability to access justice might the international legal understanding of 'Indigenous' identity have on the case? That identity is based on distinctive claims to land focused on collective ownership (Kingsbury) - a unique way of life dependent on deep cultural and often spiritual connections to land and traditional rights to own, use and access their land and its natural resources ${ }^{1}$ and a related 'view of the world characterised by a strong and often spiritual relationship with the land' (Wiessner, 2011, p. 127). How might human rights 'displacement' case-law and the English law right to abode inform the Chagos Islanders' ability to return?

The relevance of framing the Chagos case through the context of Indigenous status and land rights more broadly is novel and rarely discussed but should not be underestimated. Considering the UK's crushing defeat at the UN general assembly, ${ }^{2}$ and its antiquated approach to decolonisation, the Chagos Islands and its traditional inhabitants will certainly come under scrutiny at the international court of justice (ICJ). With it, so might conversations on land and Indigenous peoples. After the 2016 decision of the UK Supreme Court ${ }^{3}$ to dismiss the Chagossian appeal for return, international jurists will now write the

\footnotetext{
${ }^{1}$ Report of the African Commission Working Group of Experts on Indigenous Populations/Communities (2005), p. 89.

${ }^{2}$ By a margin of 94 to 15 countries, UN delegates supported a Mauritian-backed resolution to seek an advisory opinion from the ICJ on the legal status of the islands: Boycott (2017).

${ }^{3} R$. (on the application of Bancoult) (No. 2) (Appellant) v. Secretary of State for Foreign and Commonwealth Affairs (Respondent) [2016] UKSC 35.

(C) Cambridge University Press 2018. This is an Open Access article, distributed under the terms of the Creative Commons Attribution licence (http://creativecommons.org/licenses/by/4.0/), which permits unrestricted re-use, distribution, and reproduction in any medium, provided the original work is properly cited.
} 
next chapter. My hope is that the novel and critical legal arguments extended in this paper on matters such as the applicability of Indigenous status to the Chagos Islanders might be of practical use to lawyers advocating the case on behalf of the Chagos Islanders in a context of decolonisation, self-determination, ongoing colonialism, access to justice and the rule of law. I suggest that the arguments extended here are made unique through a critical rereading of the case and surrounding narrative from a third-world approach to legal scholarship, otherwise known as TWAIL theory (Mutua and Anghie, 2000; Anghie, 2007). Viewing the Chagos case from a TWAIL perspective is new and may offer some clues on why Chagossians are consistently denied formal legal recognition of their rights to land, resulting in the failure of substantive justice for Chagossians in terms of fair compensation and, should they wish, the right to return. I argue that Chagossian communities enjoy legal rights to land and related remedies of compensation and return through several legal methods: application of the international legal definition of 'Indigenous', within the Magna Carta right to abode and indirectly through 'collateral' international human rights law concerning 'displacement'-related violations. The inability of those rights to be meaningfully applied to the Chagossians in any way - as 'fundamental' ownership rights or collateral legal rights to land - is constrained because of the way those rights are routinely legally interpreted according to ongoing colonial narratives. I think about how those potential rights might apply to this case and, through a postcolonial lens, consider why those avenues have repeatedly fallen short in their application and ability to provide a right to return for Chagossians; in this way, I extend a unique approach to the case.

For example, I show that, as currently applied, the international legal definition of Indigenous is profoundly Eurocentric, making it difficult for Chagossians to access the canon of Indigenous rights and protection under international law through a common legal standard. I apply what Povinelli (2011) calls the Western legal concept of 'governance of the prior' concerned with protecting 'prior power' and 'prior occupation', to see how the paradigm collapses in the Chagos case and in several other global social contexts in which land-connected communities claim formal Indigenous status but fail to satisfy racialised Eurocentric conditions of Indigenous identity.

In international law, for the Chagos Islanders, an Indigenous claim could open the door for a meaningful restitution remedy for breach of Article 73 of the UN Charter concerning non-self-governing territories. Since Factory at Chorzów, ${ }^{4}$ the provision of full restitution in kind for legal violations and expropriation of property has been a bedrock principle of international law. ${ }^{5}$ In Chagos, wiping out all the consequences of an illegal act and re-establishing the situation that would have existed if that act had not been committed would translate into a resettlement remedy. Moreover, if restitution is not possible, pursuant to the Chorzów case, the alternative remedy is for payment of a sum corresponding to a value that restitution in kind would bear. Given that current estimates for resettlement amount to a sum potentially reaching up to half a billion pounds ${ }^{6}$ and on top of which could, through supporting and evolving jurisprudence, ${ }^{7}$ include further damages for loss of ancestral lands, the political pressure that such a legal claim provides is compelling.

\footnotetext{
${ }^{4}$ Factory at Chorzów (Germany v. Poland), Merits, Judgment, PCIJ Reports 1928, Series A 17.

${ }^{5}$ Ibid., at para. 47 , stating how reparations must, as far as possible, wipe out all the consequences of an illegal act and re-establish the situation, which would have existed if that act had not been committed. This can be achieved by restitution in kind or, if this is not possible, payment of a sum corresponding to the value that a restitution in kind would bear.

${ }^{6} \mathrm{FCO}, 4$ August 2015, review of resettlement estimates indicative total resettlement costs between $£ 110.1$ million and $£ 462.4$ million. Available at https://www.gov.uk/government/uploads/system/uploads/attachment_data/file/450997/BIOT_Policy_ Review_of_Resettlement_Consultation_Document_Final.pdf (accessed 12 March 2018).

${ }^{7}$ Mabo v. Queensland (No. 2) [1992] 175 CLR 1 (HCA), 127: in principle, compensation is payable for loss of traditional lands; Delgamuukw v. British Colombia [1997] 3 SCR: compensation is payable for Aboriginal land rights; Yakye Axa Indigenous Community v. Paraguay [2005] Judgment of 17 June 2005 (Inter-Am Ct. H. R. (Ser. C) no. 124 (2005)): the court held that compensation granted must be guided primarily by the meaning of the land for the groups. In Australia, a compensation determination for Aboriginal groups was made (De Rose v. State of South Australia [2013] FCA 988); however, the final award of compensation in this matter was settled between the parties and the quantum kept confidential. In Griffiths v. Northern Territory of Australia (No 3) [2016] FCA 900 (Timber Creek), the Federal Court of Australia gave its first ever assessment of compensation for the impairment of native title rights and interests ordering the payment of approximately \$3.3 million to the native Ngaliwurru and Nungali Peoples. \$512,000 was awarded for economic loss, \$1.488 million
} 
Those arguing the case for Chagossians based on ongoing colonial narratives can point to the legal policies discussed in this paper. Those policies show, for example, the elimination of potentially useful land rights claims through the dilution of Magna Carta rights of abode from 'fundamental' legal rights to 'important' rights capable of extinguishment for economic, military and especially cynical environmental reasons, without confirming legal precedent of use for exiling a settled population. Furthermore, demonstrable at the international level is evidence of confirming legal practice for a limited and morally regressive judicial interpretation of the Article 56 'colonial clause' of the European Convention. Parochial interpretation of the article has, I will later argue, denied Chagossians access to valuable international legal instruments and case-law upon which a right to land and remedy of return could be developed. For Chagossians, the limited reading of the extra-territorial scope of the European Convention has created a legal black hole, assisting in their continued legal exclusion and dispossession.

The legal evidence presented here shows another discursive example of what O'Connell (2011) refers to in his study of case-law from India, Ireland, Canada and South Africa constitutional courts as a modern judicial 'turn' and tacit acceptance of the supremacy of neoliberal orthodoxy (and its version of human rights) to socio-economic rights and matters of public importance. For O'Connell, neoliberalism carries with it very definite understandings of which rights merit respect in a market utopia and they are fundamentally negative rights. This 'turn' sees socio-economic rights fundamentally undermined by a judicial movement involving both the discursive and material negation of the value of such rights, despite progress in their formal recognition and even constitutional entrenchment. Borrowing from Anghie (2007, p. 245), imperialist thinking ${ }^{8}$ refers to an ongoing power structure replicating colonial and neoliberal thinking on the superiority of Western culture, market forces and, by implication, private property. The latter has its roots entrenched in history and the wellanalysed political and economic governance paradigm of the 'agricultural argument' that saw only settled, intensive, exclusive and private agricultural cultivation of land as a 'proper' or 'effective' occupation of land and therefore a basis of a real land tenure system (Flanagan, 1989; Gilbert, 2007).

I argue that, in the Chagos case, imperialist thinking is demonstrable through the continuation of a legal policy that fails to question biased Eurocentric legal structures such as the definition of Indigenous and its practical interpretation that controls access to the canon of Indigenous rights and thus denies substantive equality to a group of persistently prejudiced people. ${ }^{9}$ Imperialist thinking establishes itself within legal arguments against resettlement that align with, or as O'Connell says, 'turn' towards political and economic processes overly concerned with the macro-political, financial and even ecological conservation costs of resettlement rather than the human cost of expulsion. The legal evidence presented here illustrates how the basic applicability of potentially useful land right claims has been diluted and fragmented through examples of imperialist thinking, ultimately placing brakes on the ability of Chagossians to advance Dworkin's (1985) and Bingham's (2010) conception of a morally 'thick' rule of law that translates into recognition of the islanders' traditional land connection, appropriate compensation and, ultimately, a legal right to return. In the ways set out in

in interest and \$1.3 million for solatium, or non-economic loss. This is, however, a federal decision only and subject to appeal. This case-law demonstrates how issues of compensation quantum for Indigenous land is an evolving area of legal practice.

${ }^{8}$ The term 'imperialism' refers to a context including, but wider than actual 'colonialism', in which a broader set of practices deployed by those with great power including governments, international finance institutions and corporations govern the world according to its own vision and agenda. Practices of control are varied and may or may not include actual conquest, occupation or settlement as is classically understood as colonialism. Anghie's other examples of imperialist thinking include the ongoing process of globalisation and its privileging of neoliberal economic interests and institutions such as the World Bank. Other examples include the US War on Terror with, for example, its reproduction of a new 'other': the terrorist as opposed to the savage Indigenous native.

${ }^{9}$ Committee on Economic, Social and Cultural Rights, General Comment No. 20, Non-Discrimination in Economic, Social and Cultural Rights (Art. 2, para. 2) UN Doc. E/C.12/GC/20 (2009). Paragraph 8(b) requires that substantive equality would require paying sufficient attention to groups of individuals, which suffer historical or persistent prejudice and, importantly, an engagement with and transformation of the underlying structures of control that repeat this prejudice. The paper argues that one of those systems is the international definition of Indigenous. 
this paper, the Chagos debacle becomes emblematic of yet another example of the different and now routine forms of what Saskia Sassen (2014) persuasively coined 'Expulsions', meaning ongoing struggles and resistance against different forms of expropriation, eviction or alienation, taking place within volatile economic and political landscapes. Understanding the legal processes examined in this paper might provide clues into why the Chagossian people continue their historic struggle against expulsion emanating from colonial times for legal rights to their traditional land.

\section{A history tied to land}

Understanding the sentiments behind pursuing a land claim and the right to return requires a conversation with the communities' socio-historic relationship with discrimination. Jeffery's (2011) anthropological studies provide a fascinating history of the Chagos Archipelago in which she urges recognition of the history of settlement, slavery, ethnic division, marginalisation and displacement of Chagossians as crucial to understanding modern Chagossian cultural identity and land claims. The aim of this brief historical account is to contextualise the legal case as one historically rooted in traditional land relations and conversations over Indigenous status.

Many of the smaller islands of the Indian Ocean, including the Chagos Archipelago, were unpopulated prior to European colonial expansion from the end of the fifteenth century onwards. During the colonial period, the French, Dutch and British all tried to turn Mauritius and its surrounding islands into an economically viable colony through the cultivation of sugarcane and spices. As Gilbert (2007) notes, this method of cultivation reflects classical Lockean ${ }^{10}$ land value concepts of 'effectively cultivating' land through agriculture (Gilbert, 2007) and labour to transform it into ordered, exclusive and saleable private assets: a process that was de rigeur, with wide colonial purchase. French colonisers in Africa had their own labour argument known as mise en valuer promoting a system of 'voluntary' labour in which the French would instruct Africans in the cultivation of their own lands (Prasad, 2009). From the late eighteenth century onwards, French and British colonists brought enslaved and convict labourers from Africa and British India to work on the sugar plantations, with many forming self-interests in the land through planting crops, fishing and raising animals. After emancipation, a sizeable proportion of enslaved labourers accepted work contracts to remain on the plantations, with people of African origin always in the majority in Chagos (Jeffery, 2011).

From the colonial period until their forced eviction in 1964, the Chagos Islanders cultivated a special 'Indigenous' relationship with the land, yet nothing in the jurisprudence has dealt with the issue of land rights and Indigenous status seriously. Anthropological studies have, however, provided immensely valuable findings that can be used to support an Indigenous claim for the Chagos Islanders that is based upon the legal understanding of 'Indigenous' identity identified at the start of this paper: distinctive claims to land focusing on collective ownership and a unique way of life dependent on deep cultural and often spiritual connections to land and traditional rights to own, use and access their land and its natural resources. For example, Jeffery's (2011) study demonstrates that, during 200 years of permanent settlement, Chagossians developed a range of cultural practices pointing to unique historical cultural characteristics such as their Sega music, song, language and accents, all of which are separate and distinct from other Creole cultures: practices that signify the islanders' special Indigenous connection to the islands. The same study also talks of how Chagossian people self-identify as an uprooted population in their forced removal, which itself evidences a deep psychological connection to the islands.

Interviewed Chagossians confirmed their self-identification as Indigenous, referring to generations of cemeteries in the islands as a marker of their permanent connection to the islands. ${ }^{11}$ Their

\footnotetext{
${ }^{10}$ Locke's 1690 Second Treatise of Government contains the 'agricultural' or 'cultivation' argument, with Locke proclaiming 'that labour put a distinction between them and common: that added something to them more than nature, the common mother of all, had done; and so, they became his private right', Chapter V (Of Property), s. 28, p. 306, in Laslett (1960).

${ }^{11}$ Interview with Bernard Nourice, first-generation Chagossian deported aged five years, on file with author.
} 
distinctive claim to land focuses on the unique culture and connection to the islands and its natural resources. This has been so well documented within Jeffery's anthropological studies discussed above and further exemplified within interviews discussing a way of life in which traditional fishing rights derived from the deep cultural and historic significance of fish in Chagossian culture play an essential role. ${ }^{12}$ Referring to a dossier discussing the right of return based on indigeneity that was submitted to the UN Arbitral Tribunal in around 2012, of which nothing has been heard since its delivery to the $\mathrm{UN}$, one Chagossian believes that the issue of indigeneity has been hidden. ${ }^{13}$

On one hand, preeminent legal and anthropological practitioners support the Indigenous status of the Chagos Islanders. In 2008, Minority Rights Group International opined at the government's select committee that 'based on its 40 years of working with Indigenous communities worldwide, the Chagossians do indeed constitute an Indigenous people'. ${ }^{14}$ On the other hand, as far as the British government is concerned, the Chagossians do not constitute an Indigenous people. In an official government paper headed 'Maintaining the fiction', a Foreign Office legal adviser advised the government to 'continue to argue that the local people are only a floating population', ${ }^{15}$ advising that:

'the longer that such a population remains, and perhaps increases, the greater the risk of our being accused of setting up a mini-colony about which we would have to report to the UN and fulfil our obligations to inhabitants living in non-self-governing territories under Article 73 of the UN Charter. Therefore, immigration legislation giving such labourers and their families very restricted rights of residence would bolster our arguments that the territory has no Indigenous population. ${ }^{, 16}$

Based on this legal advice, the Chagossian inhabitants and their families were deliberately characterised as a 'floating population' and 'contract labourers' rather than permanent residents with 'no permanent use of the land'. ${ }^{17}$ Furthermore, in August 2015, ${ }^{18}$ the government embarked on a three-month resettlement exercise. Chagossians rejected the terms of those proposals, which included a three-year pilot scheme during which it was suggested that Chagossians work as labourers at the military base with no formal right to abode, or right to private ownership of land. The provisions have simply recast Chagossians from Tarzans, Man Fridays, to contract labourers and now cheap temporary labour for the military base. ${ }^{19}$

The islanders' special Indigenous relationship with the land continued until 1964, when the US identified the Chagos Islands of strategic importance as a military base. In 1965, the Harold Wilson administration issued, using simple executive law-making under royal prerogative powers an order proclaiming a new 'separate colony which shall be known as the British Indian Ocean Territory (BIOT), consisting of the Chagos Islands, Aldabra, Farquhar and Desroches. ${ }^{20}$ In April

\footnotetext{
${ }^{12}$ Interview with Clifford Volfrin, first-generation deported Chagossian, on file with author.

${ }^{13}$ Note 11 above.

${ }^{14}$ Submission from Minority Rights Group International, (2008) Submission to the Select Committee on Foreign Affairs, 6 July, 31.

${ }^{15}$ Bancoult, R. (on the application of) v. Secretary of State for Foreign and Commonwealth Office [2000] EWHC 413 (Admin) (3 November 2000), para. 18.

${ }^{16}$ Ibid.

${ }^{17}$ Note 15 above and Bancoult, $R$. (on the application of) v. Secretary of State for Foreign and Commonwealth Affairs Rev 1 [2006] EWHC 1038 (Admin) (11 May 2006), at para. 15, per Hooper L.J.

${ }^{18}$ British Indian Ocean Territory (BIOT) Policy Review of Resettlement Consultation with Interested Parties 2015. Available at https://www.gov.uk/government/uploads/system/uploads/attachment_data/file/450997/BIOT_Policy_Review_of_ Resettlement_Consultation_Document_Final.pdf (accessed 12 March 2018).

${ }^{19}$ During the All Party Parliamentary Group it was noted that these provisions are aimed at scaring the Chagossians with an insecure future and that none of the provisions addresses any of the real issues at stake: that of correcting wrongdoing and the ongoing subversion of rights and justice of an Indigenous population.

${ }^{20}$ British Indian Ocean Territory Order 1965 (8 November 1965), Statutory Instruments [1965] No. 1920 as amended in Statutory Instruments (1968) No. 111.
} 
1971, the Commissioner of BIOT enacted an ordinance to clear the Chagos Islands of their 'extremely unsophisticated' inhabitants. ${ }^{21}$ In exchange for a US\$14 million discount on the Polaris nuclear missile programme, the UK government agreed to depopulate the Chagos Archipelago and lease one of the islands, Diego Garcia, to the US government for 50 years (Allen, 2014). The British government paid compensation of circa $£ 2,976^{22}$ to each Chagossian exiled to Mauritius, whilst those sent to the Seychelles received nothing.

In 2000, the Chagossians' legal team won their judicial review of the 1971 BIOT Immigration Ordinance, with the divisional court allowing the appeal. ${ }^{23}$ The then-Foreign Secretary announced that the government will not appeal the decision. The government introduced a new BIOT Immigration Ordinance that theoretically permitted Chagos Islanders to return to the outer islands, creating a clear legitimate expectation of return. ${ }^{24}$ However, in 2004, the government used a new 'Orders in Council' through royal prerogative in which Article 9 set the territory aside for 'defence purposes', stating that 'no person has the right of abode in the Territory'. ${ }^{25}$ Following a successful appeal by the Chagossians to the High Court striking down the sections of the 2004 orders prohibiting resettlement, the Foreign and Commonwealth Office appealed to the House of Lords, which upheld the legality of the expulsion, and the 2004 Orders in Council.

The aim of this brief historical account was to contextualise the legal case as one historically rooted in traditional land relations, discriminatory narratives, eviction policies and contested debates over Indigenous status that have all worked to rob communities of their traditional land relations. Consequently, it starts a conversation that, through evidence extended in this paper, throws icy water on Hoffman's view of the case as vexatious and 'like Bancoult 1, a step in a campaign to achieve a funded resettlement'. ${ }^{26}$

\section{Post-colonial bias within the Indigenous definition: dis-application beyond Chagos and 'salt water'}

UN texts contain three different approaches to the issue of who is Indigenous. Arguably, the most comprehensive attempt at a working definition is found in the 1983 report of the UN Special Rapporteur on the Prevention of Discrimination and Protection of Minorities, Martínez Cobo (1986/87). This identified Indigenous people as 'having a historical continuity with pre-invasion and pre-colonial societies that developed on their territories', which 'consider themselves distinct from other sectors of the societies now prevailing on those territories, or parts of them' and deriving from 'non-dominant sectors of society'. Indigenous people are also 'determined to preserve, develop and transmit to future generations their ancestral territories and their ethnic identity, as the basis of their continued existence as peoples, in accordance with their own cultural patters, social institutions and legal system'.

Since then, other legal and policy-led definitions have been advanced. At least seven criteria of 'Indigenousness' can be distilled from these definitions. It is understood that most communities will not be able to satisfy all criteria but, when viewed holistically, the definitions create a sliding scale for the purposes of assessing indigeneity. ${ }^{27}$ These criteria generally involve evidence of communal attachment to place, historical precedence, experience of severe disruption, dislocation and exploitation, historical continuity, ongoing oppression/exclusion by dominant societal groups, distinct ethical/cultural groups and self-identification as Indigenous people (Allen, 2007). In 1989, the UN

\footnotetext{
${ }^{21} R$. (On the Application of Bancoult) v. Secretary of State for Foreign and Commonwealth Affairs [2008] UKHL 61.

${ }^{22}$ Chagos Islanders v. United Kingdom [2012] No. 35622/04, ECHR 2012, at para. 12.

${ }^{23}$ Bancoult, $R$. (on the application of) v. Secretary of State for Foreign and Commonwealth Office [2001] QB 1067.

${ }^{24}$ Note 21 above, at para. 133, per Lord Mance.

${ }^{25}$ British Indian Ocean Territory (Constitution) Order, dated 10 June 2004, Art. 9.

${ }^{26}$ Note 21 above, at para. 55.

${ }^{27}$ Note 14 above.
} 
adopted a more inclusive approach to indigeneity prioritising self-identification ${ }^{28}$ and, in 2007 , the non-binding United Nations Declaration on the Rights of Indigenous Peoples was adopted by 143 Member States (including the UK) and contains perhaps the most purposive and flexible approach to the issue in that it is utterly silent on the point.

States frequently challenge this 'open door' policy of self-identification based on the assumption that the special relationship with land is a threat to sovereignty and social cohesion (Kymlicka, 1995). Waldron (2003) argues against self-identification based on excessive dilution such that any communities can claim indigeneity, opening the door to vexatious claims. Given these disparate understandings of the term, where does the law currently stand? Determining the question of Indigenous status is, I argue, not a simple matter of analysing the black letter law, but equally, and perhaps more importantly, requires a practical state-of-the-art look at the use of the term in real-world contexts to understand policy practice and application of the term. This contextual approach provides an evidence-based approach informing us about which of the plural legal definitions discussed above is currently in vogue.

Despite the above legal evidence of a growing movement towards a more purposive definition based on self-identification, the practical application of Indigenous status in different international contexts falls short of that textual approach. In a 2000 Working Paper, the Economic and Social Council ${ }^{29}$ hit on the hidden problematic assumption surrounding application of the definition in plural legal contexts. That problem concerns the modelling of the current international definition of Indigenous as based on the 'blue or salt water doctrine'. The argument runs that the legal definition only gives recognition to one type of 'transnational' historical context in which Indigenous people are those people beyond Europe who lived in the territory before European colonisation and settlement. ${ }^{30}$ The paper goes on to note how the approach to the drafting of Indigenous rights has been influenced mainly by developments in the Americas and in the Pacific region, making Indigenous identity profoundly America-centric.

In addition to the dual requirements of Indigenous people living in a place or territory requiring the act of crossing 'salt water' and experiencing an encounter with European colonisation is one more curious assumption. This requirement fixates over European conceptions of indigeneity that focus on restrictive ideas of 'original' aboriginality or 'who came first' and persons belonging to a territory 'since time immemorial'. This attachment to the 'prior' is part of a larger Western concept favouring 'prior' power that Povinelli (2011) calls the 'governance of the prior' and, she argues, forms settled law from the writings of Blackstone. ${ }^{31}$ The problem with this type of originalist assumption is its deeply exclusionary effects in social contexts that do not fit this vision of European colonisation, yet in which groups claim a special Indigenous attachment to the land.

Kingsbury has commented on the negative effects of extending the definition to Asiatic contexts: contexts that share no settler colonial history. Based on his study of land-connected communities in China, India, Bangladesh and Myanmar, he calls for a modern reconceptualisation of the definition to recognise communities who have either staved off Western colonialism or rid themselves of its most

\footnotetext{
${ }^{28}$ Article $1(2)$ of the International Labour Organisation (ILO) Convention No. 169 states that 'self-identification as Indigenous or tribal shall be regarded as a fundamental criterion for determining the groups to which the provisions of this Convention apply'.

${ }^{29}$ UN Sub-Commission on the Promotion and Protection of Human Rights (2000), Prevention of Discrimination Against and the Protection of Minorities: Working Paper on the Relationship and Distinction Between the Rights of Persons Belonging to Minorities and those of Indigenous Peoples, 19 July, E/CN.4/Sub.2/2000/10.

${ }^{30} \mathrm{Ibid}$., note 3, noting the blue/salt water concept holds that Indigenous people consist of those beyond Europe who lived in a territory before European colonisation and settlement and who now form a non-dominant and culturally separate group in the territories settled primarily by Europeans and their descendants. It is profoundly relational to European settlement.

${ }^{31}$ Povinelli notes that foundational texts such as William Blackstone's Commentaries of the Laws of England extended legitimacy to a wide range of seizures of property, persons and territory that were all anchored in a way of thinking about the jurisdiction of laws pertaining to the 'rights of the prior'. These, she notes, were all articulated and manipulated through the still emergent notion that what held must hold until it is purchased (or gotten by treaty), forced to give way (through conquest or genocide) or characterised as never having existed (such as in the concept of terra nullius).
} 
direct effects in their struggle for independence and see efforts to impose the European 'salt water' concept of Indigenous as a form of neocolonialism (Kingsbury, 1998). In those factual cases, he advises that, in order to prevent the illiberal effects of a parochial Eurocentric legal policy, the legal 'signifiers' of Indigenous status discussed above should be indicators and not definitive positivist requirements.

In the African context, fulfilling requirements over originality is also difficult and not very constructive. ${ }^{32}$ Limiting the term 'Indigenous' to those local peoples still subject to the political domination of the descendants of colonial settlers makes it very difficult to employ the concept in Africa. Except for a few communities that migrated from other continents or settlers from Europe, all Africans can claim to be Indigenous people of the continent and nowhere else. ${ }^{33}$ So, within this common heritage of aboriginality, African people have migrated for centuries from various parts of the continent: with wars of conquest shaping the character of nationalities. In this context, White settlers and colonialists have not exclusively practised domination and colonisation, as dominant groups have also repressed marginalised land-connected pastoralist and forest-dwelling groups since independence. It is this sort of present-day internal repression within African states that the contemporary African Indigenous movement seeks to address ${ }^{34}$ and, by default, legal definitions of 'Indigenous' fixated with prior occupation have the potential to exclude. In practice, this means that Eurocentric distinctions are probably much less useful for standard-setting concerning group accommodation in Asia and Africa, where dominant and non-dominant groups within the state can all claim aboriginality and discrimination against their traditional land ties from both colonial settlors and internal communities.

Consequently, the African Commission on Human and Peoples' Rights (African Commission) concludes that, in the African context, those applying the term 'Indigenous' do so as a 'movement' to address their human rights situation that cuts across various socio-economic systems to embrace hunter-gatherers, pastoralists and small-scale farmers: the many diverse groups of land-dependent people that identify with the Indigenous movement yet have struggled for recognition of their basic human rights. ${ }^{35}$ The African Commission has adopted a 'socio-psychological' understanding of indigeneity, setting out broad criteria but prioritising (as in the UN system) self-definition. Examples of hunter-gatherers and forest dwellers claiming Indigenous legal status include the Hadzabe of Tanzania and the Ogiek of Kenya, who won a landmark victory in the African Court of Human and Peoples Rights ${ }^{36}$ relating to state encroachment over their traditionally held land. The case recognised the Ogiek's Indigenous status and rights to land derived through violations of their rights to property, religion and culture by the Kenyan government under the African Charter on Human and Peoples Rights.

Like the Asian and African examples discussed above, the Chagossians are not a society that European powers had crossed over 'salt water' to encounter, settle and conquer. They are not a 'preinvasion' society of 'first inhabitants' who assert historical precedence and consequently have 'encountered' mass European colonisation. Understood as a factual block to a legal claim in Indigenous status is the specific Chagossian history of descent from enslaved labourers from Africa and, later, indentured labourers from the Indian sub-continent. From a post-colonial TWAIL lens, this fact pattern supports arguments regarding international law's bias towards Western states, despite its claims to universality (Anghie, 2007). Such a repressive legal position continues the Chagossians' expulsion by denying their special connection to the islands evidenced in the previous section through Jeffery's studies of the Chagossians' distinct cultural characteristics of Sega music, song, language and accents that signify

\footnotetext{
${ }^{32}$ Except as the African Commission on Human and Peoples' Rights notes, in certain very certain very clear cases like the San of Southern Africa and the pygmies of Central Africa, in the report of the African Commission's Working Group of Experts on Indigenous Populations/Communities (2005), 92.

${ }^{33}$ Ibid.

${ }^{34}$ Ibid.

${ }^{35}$ Pastoralist communities include the Pokot of Kenya and Uganda, the Barabaig of Tanzania, the Maasai of Kenya and Tanzania, the Ogoni (mainly farmers and fishermen) of Nigeria, the Berbers of North Africa and the Samburu, Turkana, Rendille, Orma and Borana of Kenya and Ethiopia, see African Commission on Human and Peoples' Rights, Indigenous Peoples in Africa: The Forgotten Peoples? (2006), p. 10.

${ }^{36}$ African Commission on Human and Peoples' Rights v. the Republic of Kenya, 26 May 2016, Application 006/2012.
} 
the islanders' special 'Indigenous' connection to the islands. Interviews with evicted Chagossians also evidence a deep psychological connection to the islands - a way of life deeply dependent on the cultural and historic significance of fish and fishing rights in Chagossian culture and the trauma caused by the forced breakage of this distinctive way of life and livelihood intimately connected to their traditional land in the islands. Viewed holistically, each of the preceding characteristics can be conceptualised as strong indicators of Chagossian Indigenous status. Those hallmarks of Indigenous status do not fixate over 'prior power' or 'governance of the prior' paradigms and instead present a modern reconceptualisation of the definition that gives legal protection to the human rights and social situation of the many diverse groups of land-dependent people (of which the Chagos Islanders self-identify as one such people) that identify with the Indigenous movement due to their struggles to protect and preserve their traditional land relations that are persistently threatened by eviction and discrimination, as exemplified in this case.

The above comparative examples emanate from continents and countries typically not associated with Indigenous people. They demonstrate how this type of land-related discrimination experienced by communities with special social, cultural and spiritual connections to land have occurred and continue to occur both within and outside of Western colonial domination. Deficits in legal recognition and protection are, I argue, a direct result of advancing a legal definition that clings to a European culture such that it has an implicit bias towards recognition of people who have experienced Western colonisation by a Western power ruling a geographically and racially distinct territory somewhere 'over there' beyond 'salt water' and over peoples defined as 'original' inhabitants over which European powers can form a fictional construct of prior governance to force land-connected groups to relinquish, through conquest or eviction (Povinelli, 2011), their prior land rights. More worrisomely, it detracts attention away from the common denominator shared by all peoples claiming Indigenous status: the golden thread of their way of life that coalesces around a special social, cultural and often spiritual connection to land that defies and unites the diverse social context of groups and has been the subject of discriminatory practices of encroachment and expulsion. It is this core characteristic of a way of life depending on access and rights to traditional land that requires protecting. Based on this practice, I argue that legal assignment of 'Indigenous' status is best determined on a case-by-case basis and always with its essence read in the context of the effects of discrimination on a global movement of people ${ }^{37}$ who share a special relationship with land. Such a reading would accommodate Chagossian communities.

Turning to jurisprudence, there is a generally overlooked yet nascent supporting legal practice of recognising legal ties to land for Indigenous communities in non 'blue water' contexts. In Western Sahara, the ICJ extended legal recognition to a tribal community based on its essentially different land-related customs 'concerning the use of water-holes, grazing lands, cultivated lands, burial grounds and agricultural lands ... which were regulated by custom' ${ }^{38}$ In Saramaka v. Suriname, the Inter-American Court of Human Rights expanded access to the Indigenous canon of rights to post-colonial descendants of African slaves. The case expressly recognises that post-colonial tribal groups can, even though not first occupants, share similar characteristics with Indigenous groups, such as having social, cultural and economic traditions different from other sections of the national community and regulating themselves, at least partially, by their own norms, customs and traditions. ${ }^{39}$ Moreover, Pedra Branca ${ }^{40}$ recognised the ties of loyalty of the Indigenous Orang Laut 'people of the sea' to the Malaysian Sultan of Johor and used those historic ties as valuable evidence towards the legal finding that Malaysia has original title to the Pedra Branca islands, rather than Singapore (Huh, 2015).

\footnotetext{
${ }^{37}$ Interview with Lucy Claridge, former Head of Law, Minority Rights Group, on file with author.

${ }^{38}$ Western Sahara, Advisory Opinion, Judgment, ICJ Reports 1975, 152.

${ }^{39}$ Saramaka People v. Suriname, Judgment of 28 November 2007 (Inter-Am. Ct. H. R. (Ser. C) no. 172) (2007)), at para. 79.

${ }^{40}$ Case Concerning Sovereignty over Pedra Branca/Pulau Batu Puteh, Middle Rocks and South Ledge (Malaysia/Singapore) (Pedra Branca case), Advisory Opinion, Judgment, ICJ Reports 2008, 12.
} 
In Endorois, ${ }^{41}$ the African Commission extended the concept of indigeneity into the post-colonial African context when it recognised the land rights of the pastoralist Endorois communities upon their eviction from the Kenyan Rift Valley. Finally, it should not be overlooked that the seminal domestic case of Mabo v. Queensland (No. 2) gave a socially unbounded context to the legal application of native title, stating how the 'nature and incidents of native title must be ascertained as a matter of fact by reference to those laws and customs' ${ }^{42}$ Thus, the basic legal rule in Mabo does not preclude purposive application. Arguably, since Mabo, the definition has been understood and applied in a socially restrictive context of English settler-colonialism, which, whilst an excellent starting point, presents a legal lacuna for groups from wider social contexts. Cross-fertilisation and purposive use of this body of law might, if strategically used, assist the Chagossians in securing legal recognition in forthcoming international adjudication concerning sovereignty.

Crucially, these cases move towards an appreciation of Indigenous distinctive 'otherness' as based on a special relationship with the land that has been the subject of historic and ongoing coercion and force, the point being that 'specialness' is removed from culture and ethnicity - concepts that can be easily categorised in the interests of those with greater power (Fanon, 1967) - and manipulated or racialised $^{43}$ to resonate colonial understandings of Indigenous people. And we find in the Chagos case first-hand evidence of just how the Indigenous label might be racialised when connected to ethnicity and culture. For example, the wicked political policy of dispossession has been supported through offensive language stating how 'unfortunately along with the Birds go some few Tarzans or Men Fridays whose origins are obscure, and who are being hopefully wished on to Mauritius'. ${ }^{44}$ Moreover, in the 2008 House of Lord's judgment, when commenting on the Chagossians' right to return, Lord Hoffman echoes the language of 'Man Friday' when he dismisses return based on his interpretation that Chagossians have shown no inclination to return to live 'Crusoe-like' in poor and barren conditions of life. ${ }^{45}$ His description of how 'each family had a house with a garden and some land to provide vegetables ... they also did some fishing ... and into this innocent world there intruded, in the 1960s, the brutal realities of global politics' creates a type of nostalgia and false romanticism that works to divert attention away from framing Chagossian identity in terms of indigeneity. Like Wolfe's argument that acts of Indigenous dispossession itself work to make the Indigenous subject improper (Wolfe, 2006), the imagining of this fictional imagery of Chagossians as Men Friday and Crusoe-like is not the original Friday of Defoe's Robinson Crusoe, but 'this Friday is a historically and geographically de-contextualised "native": an abstraction, under imperialist rubrics of savagery, amenable to slavery' (Jones and Motha, 2015, p. 259), which carries an improper, othering effect. There is a dark meaning to the response of a Chagossian gentleman when asked why he feels they have been treated differently, and he replies by pointing to his skin: 'le peau,' he says. ${ }^{46}$

\section{Fragmenting the right to abode through judicial construction}

Chapter 29 of the Magna Carta reads that 'no freeman shall be taken, or imprisoned ... or exiled, or any otherwise destroyed but by the lawful judgement of his peers, or by the law of the land'. These rights translate as legal rights to abode and to return to one's homeland. Contemporary legal practice

\footnotetext{
${ }^{41}$ 276/03 Centre for Minority Rights Development (Kenya) and Minority Rights Group International on behalf of Endorois Welfare Council v. Kenya, African Commission on Humans and Peoples' Rights, 46th Ordinary Session, 25 November [2009].

${ }^{42}$ Mabo v. Queensland (No. 2) (1992) 175 CLR 1 (HCA), 64.

${ }^{43}$ Claridge, note 37 above.

${ }^{44}$ UKNA, FCO 371/190790, DA Greenhill Foreign Office Deputy Under Secretary to P Gore-Booth Foreign Office Permanent Under Secretary 24 August 1966 and OT 423: Written Evidence from Mr Abhimanu Kundasamy, High Commissioner of Mauritius. Available at www.publications.parliament.uk/pa/cm200910/cmselect/cmfaff/memo/overseas/ ucm42302.htm (accessed 14 March 2018).

${ }^{45}$ Note 21 above, at para. 5.

${ }^{46}$ Volfrin, note 12 above.
} 
understands Magna Carta rights as playing a formative and 'embryotic' role in the development of English law, the rule of law and international human rights law (Bingham, 2010, pp. 12-13).

When Sedley L.J. observes how 'the two Orders in Council negate one of the most fundamental liberties known to human beings, the freedom to return to one's own homeland however poor and barren the conditions of life, ${ }^{47}$ we are reminded of the fundamental importance of Magna Carta rights to English legal practice. Likewise, for Bingham, 'the principle that every state must admit its own nationals to its territory is accepted so widely that its existence as a rule of law is virtually beyond dispute. ${ }^{48}$ Citing Van Duyn ${ }^{49}$ the judges held that 'it is a principle of international law ... that a state is precluded from refusing its own nationals the right of entry or residence'.

Yet, remarkably, despite repeated application of authoritative legal opinion confirming the fundamental, constitutional and non-derogable nature of the right to abode, the Chagos case successfully dis-applied the right to British citizens using what Lord Bingham referred to in Bancoult 2 as 'anachronistic $^{50}$ legislative powers. Indeed, a worrisome hallmark of the Chagos case is the repeated and overzealous use by the executive of a legitimate but extreme form of power: the royal prerogative. The defining characteristic of prerogative power is that its exercise does not require the approval of parliament and is thus far removed from the modern archetype of legitimate law-making, which, in the British polity, is the act of parliament (Poole, 2010). Consequently, when implemented, it necessitates a careful historical inquiry to ascertain whether there is any precedent for the exercise of the power in the given circumstances.

Although the scope of the prerogative powers is difficult to determine,${ }^{51}$ some highly specific situations envisage its use, including governance of the armed forces, an event of grave national emergency, ${ }^{52}$ powers to keep the peace where no emergency exists, to grant pardons and to authorise independent public inquiries. ${ }^{53}$ In the House of Lords, Bingham dismissed the government's appeal, stating that the denial of the right to abode in Article 9 of the BIOT Constitution order was unlawful because it was irrational in the sense that there was, quite simply, no good reason for making it. ${ }^{54}$ Lord Mance found no historical precedent for a similar use of prerogative power to evict a population of persons, remarking his 'surprise' if any supporting precedent could be found ... 'and none has been shown' ${ }^{55}$

Both dissenting judges Mance and Bingham interpret the Magna Carta right to abode as fundamental $^{56}$ and constitutional. Consequently, the unfairness and irony that an executive command or 'a constitution which exiles a territory's inhabitants is a contradiction in terms' are not lost on Mance. He draws comparatively from other territorial disputes, noting that the UK is currently embroiled in three separate territorial disputes over the Falklands, Gibraltar and the Chagos Islands, and has treated all of them differently. Territories such as Gibraltar or Malta have been ceded or conquered for military purposes but, as Mance notes, 'never ... has there been either an original purpose or a subsequent attempt compulsorily to exclude their natural inhabitants' and to treat those territories as just 'bare land'. ${ }^{57}$ Yet, the UK has 'recognised the permanence of the populations in Gibraltar and the Falklands, extending a right to self-determination and permitting those citizens to be

\footnotetext{
${ }^{47}$ Secretary of State for the Foreign and Commonwealth Affairs $v$. The Queen (on the Application of Bancoult) [2007] ECWA Civ. 498, at para. 71 .

${ }^{48}$ note 21 above, at para. 70.

${ }^{49}$ Van Duyn v. Home Office (Case 41/74) [1975] Ch 358, 378-379.

${ }^{50}$ Note 21 above, at para. 69.

${ }^{51}$ The Governance of Britain Review of the Executive Royal Prerogative Powers: Final Report, Ministry of Justice, October 2009, para. 27.

${ }^{52}$ Burma Oil Company (Burma Trading) Ltd v. The Lord Advocate [1965] AC 75, such as use of the prerogative by the army to destroy private property to prevent it from falling into the hands of an advancing enemy.

${ }^{53}$ Note 51 above, which sets out several circumstances in which prerogative powers can be used.

${ }^{54}$ Note 21 above, at para. 72 .

${ }^{55} \mathrm{Ibid}$., at para 150 .

${ }^{56} \mathrm{Ibid}$., at para. 151.

${ }^{57}$ Note 11 above, at para. 157.
} 
on the UN list of non-self-governing territories since 1946 and has extended to those citizens' protection under the 'sacred-trust' of Article 72 in the UN Charter. ${ }^{58}$ The uneven legal application of the law is not lost on Chagossians: 'we have never had good or equal treatment with other British citizens. Why are tourists able to go there and we cannot? Why were we exiled and other inhabitants of overseas territories, like the Falklands, not? ${ }^{59}$

Delivering the majority view, Hoffman extends a legal analysis that deems executive application of prerogative powers for Chagossian expulsion entirely reasonable. He dilutes or demotes the right of abode through a legal interpretation, formulating it as an 'important right' but not a constitutional one and not 'in its nature so fundamental that the legislative powers of the Crown simply cannot touch it. ${ }^{60}$ In other words, the right of abode is capable of abrogation and dis-application through executive power or, as Hoffman responds, the right of abode is a creature of the law: the law gives it and the law may take it away. ${ }^{61}$ Since Chagos, the $2014 \mathrm{HS2}^{62}$ case has provided intriguing Supreme Court debate over the potential normative hierarchy within English law of specific 'fundamental principles'. Given the court's explicit reference to Magna Carta rights as fundamental principles, that decision might offer crucial precedent confirming an evolving legal practice recognising non-derogable rights that include Magna Carta, under English law. When read against the later HS2 case, Hoffman's earlier interpretation of the Magna Carta right to abode as 'important' but not 'constitutional' looks inconsistent.

The executive insistence on using prerogative powers in Chagos follows a consistent political practice. After Bancoult 1, Robin Cook announced that the immigration controls imposed by the 2000 Ordinance were to be revoked, and that the government was to introduce a new BIOT Immigration Ordinance that theoretically permitted Chagos Islanders to return to the outer islands. Reneging on this promise, in 2004, the government used a new 'Orders in Council' through royal prerogative, with Article 9 setting the territory aside for 'defence purposes' and stating that 'no person has the right of abode in the Territory. ${ }^{63}$ A legal challenge over whether Cook's statements amounted to a legitimate expectation of Chagossian resettlement ensued.

The leading case of R. v. North and East Devon Heath Authority, Ex p Coughlan ${ }^{64}$ clarifies when public authorities are required to honour their statements of policy or intention when their acts have created a legitimate expectation of some substantive ultimate benefit or procedural expectation. As Bingham noted in R. v. Inland Revenue Commissioners, legitimate expectation is rooted in the doctrine of fairness, ${ }^{65}$ requiring the courts to consider that value when judging the adequacy of the reason advanced for the governmental change of policy that gave rise to the legitimate expectation. Typically, legitimate expectations refer to the possible outcomes of substantive legitimate expectations as the claimant's interest in some ultimate benefit, and not only to procedural expectations typically a promise of being consulted. The expectation arises not because the claimant asserts any specific right to a benefit, but because his interest in it is one that the law protects through requirements of

\footnotetext{
${ }^{58}$ The UK government did not recognise that the Chagossians constitute a permanent population of the BIOT, consequently denying that it is subject to obligations of a 'sacred-trust' under Art. 72 of the United Nations Charter to 'ensure ... [the] economic, social and educational advancement' of the residents of which forced exile would be in clear legal contravention.

${ }^{59}$ Volfrin, note 12 above.

${ }^{60}$ Note 21 above, at para. 45 .

${ }^{61}$ Ibid.

${ }^{62}$ R. (HS2) Action Alliance Ltd) v. Secretary of State for Transport [2014] UKSC 3, debating the possibility that all constitutional legislation might not be equal and that there might be an ordering of specific fundamental constitutional norms and statutes deriving from inter alia Magna Carta, the Petition of Right 1628, the Bill of Rights, the European Communities Act 1972, the Human Rights Act 1998 and the Constitutional Reform Act 2005.

${ }^{63}$ British Indian Ocean Territory (Constitution) Order, dated 10 June 2004, Art. 9.

${ }^{64}$ [2001] QB 213, 57.

${ }^{65}$ R. v. Inland Revenue Commissioners ex p. MFK Underwriting, legitimate expectation is rooted in the doctrine of fairness [1990] I W.L.R. 1545, 1570, per Bingham L.J.
} 
procedural fairness. Examples of legitimate expectations of a substantive benefit include the promise of a home for life, a benefit or commodity such as a welfare benefit or licence. ${ }^{66}$

For Mance and Bingham, Cook's press statements created a clear and substantive legitimate expectation of return. ${ }^{67}$ In an approach that resonates with Bingham's rooting of legitimate expectations in fairness and a morally 'thick' rule-of-law approach to legal interpretation, Mance remarks that any questions of departing from this legitimate expectation of return is ultimately one of reasonableness and fairness ${ }^{68}$ and not to be automatically sacrificed to political interests. Contrastingly, Hoffman's construction of the legal principle of 'legitimate expectations' reads Cook's statement as coming 'in my opinion ... nowhere near a promise' and is stripped bare of any moral content. Hoffman goes on to say that, even if it could be so construed as amounting to a promise of return, there was a 'sufficient public interest justification for the adoption of a new policy in 2004' because the 'rights withdrawn were not of practical value to the Chagossians' and that the decision was very much concerned with the 'macro-political field'. ${ }^{69}$ This changed 'macro-political field' justifying the 2004 order specifically related to imperialist concerns such as changed security situation after $9 / 11$, the prohibitive costs of resettlement, ecological costs of resettlement in the atolls and the UK's continued co-operation with an important ally in maintaining an important and secure defence installation on Diego Garcia. ${ }^{70}$

In contrast, Mance is critical of Hoffman's recognition of the islands as sites of purely monetary and military interests, stating how Hoffman is wrong to conflate these separate considerations and to dismiss from consideration the legal freedom to return and all that it represents for the human spirit on the basis that return is impractical or uneconomic. ${ }^{71}$ Hoffman's judgment of the law on legitimate expectation in the Chagos case stands in stark contrast to the minority judgments of Bingham and Mance. Their judgments hold that questions over departure from the legitimate expectation to return should be carefully considered against questions of fairness, decency and reasonableness, and are thus not for automatic sacrifice to political expediency. When read against those views, Hoffman's judgment on the same point appears morally regressive, and even wicked. This tense judicial tussle also provides another example of the battle surrounding O'Connell's modern judicial 'turn' in which neoliberal orthodoxy compete and vie with socio-economic rights, matters of public importance and fairness. By a slim judicial majority, the discursive and material negation of Magna Carta rights to return have, in this case, been fundamentally eroded in favour of political and economic preference.

The next Bancoult chapter is particularly cynical in the deployment of environmental protection language as a new imperialist paradigm through which the UK government has prevented return. Bancoult $3^{72}$ involved Olivier Bancoult's appeal against the creation of the 2009 marine protection area (MPA). Bancoult alleged the decision to declare the MPA in BIOT flawed by an improper motive (to prevent the return of Chagossians) evidenced by leaked notes recording a meeting with BIOT officials. Specifically, the disclosure established that a marine park would prevent the resettlement claims of the archipelago's former residents. ${ }^{73}$ The MPA consultation paper ${ }^{74}$ contains only one reference to the Chagossians, is ambiguous as to what the MPA would practically entail and is not clear what legal authority, if any, it is based upon. The second ground for appeal revolved on Bancoult's argument that the MPA decision was flawed by its failure to disclose that its creation would adversely affect the historical and traditional rights of Chagossians to fish in the waters of their homeland as Mauritian

\footnotetext{
${ }^{66}$ Ibid., at para. 62 .

${ }^{67}$ Note 21 above, at para. 133.

${ }^{68}$ Ibid., at para. 177 .

${ }^{69}$ Ibid., at para. 63 .

${ }^{70} \mathrm{Ibid}$., at paras 26, 27, per Hoffman, and 132, per Carswell.

${ }^{71}$ Ibid., at para. 172, per Lord Mance.

${ }^{72}$ Regina (Bancoult) v. Secretary of State for Foreign and Commonwealth Affairs (No 3) [2014] WLR (D), at para. 9.

${ }^{73}$ Note 21 above.

${ }^{74}$ FCO Consultation Document: Consultation on Whether to Establish a Marine Protected Area in the British Indian Ocean Territory, (date unknown) with the one reference to native Chagossians, p. 13. Available at https://www.iucn.org/sites/dev/ files/import/downloads/mpa_consultation_101109.pdf (accessed 14 March 2018).
} 
citizens and the native population of the Chagos Islands and to deprive Chagossians of an important source of food and livelihood. ${ }^{75}$ The practical effect of the MPA was to sever the Chagossians' last remaining cultural link with the islands on ecological grounds. The legal response to the appeal harmonised with the executive decision to create the MPA with legal arguments peppered with references relating to the overall environmental, development and climate-change benefits resulting from the creation of the MPA. ${ }^{76}$

Arguably, these examples of legal interpretation evidence judicial support to imperialist arguments forwarding the benefits of civilisation, modernity, developmental and private property, ${ }^{77}$ and now environmental protectionism. This type of 'environmental' executive dialogue betrays a new brand of imperialism that prioritises political, market and military power for their familiar benefits of civilisation, modernity and development, and now 'environmental protectionism' as a new advantage supporting the continuation of the macro imperial project over the Chagossians' traditional land rights. The result is one of a 'fortress conservation' model devoid of Indigenous inhabitants for reasons of environmental protection ${ }^{78}$ : a kind of environmental nullius.

As Hulme and Murphree (1999) note, policies and practices of conservation in Africa have begun to shift away from the fortress conservation 'state is best' models to more community-based approaches; however, neither of these models provides a panacea for conservation solutions. In Hulme and Murphree's view, both approaches can be used to buttress neoliberal economic thinking that has dominated the late twentieth century and argues that unfettered markets give individuals the greatest freedom in choosing what to produce and consume. When translated into a conservation context, the logic of unfettered markets works to prioritise patterns of natural resource and conservation as being best determined by political and economic purpose and expediency. ${ }^{79}$ In Chagos, the use of the islands and its resources are best served by more 'useful' means of UK-US political relations, geopolitical military interests and now via dubious 'state is best' fortress conservation efforts, all of which continually trump the protection of traditional land interests.

This conservation episode is yet another politico-legal episode along with those examined previously on the closing-down of formal Indigenous recognition, the repetitive political use of domestic royal prerogative power without confirming legal precedent, dilution of the islanders' legitimate expectation of return and, as the next section will discuss on the judicial hardening of territoriality rules, that serve the perpetual sacrifice of the Chagos Islanders' traditional land rights and rights to return for neoliberal imperialist thinking and thus support this paper's reading of the Chagos case from a TWAIL-focused lens.

Other examples of this environmental nullius policy include the displacement of the Indigenous Ogiek people from the Mau Forest in Kenya to make way for the government's conservation plans in the form a national park, which would generate enormous economic revenue, whilst leaving the Ogiek disposed of their land and in poverty. In an (unsuccessful) application before the African Commission, the Kenyan government justified the eviction based on actions by colonial and postindependence governments to protect the Mau Forest in view of its importance to the country and the region's ecology, biodiversity, resources and economic activities. ${ }^{80}$ Similar arguments were raised by the Kenyan environmental agencies in the Endorois case to bolster the case for dispossession of the Masai. ${ }^{81}$ As Young notes, the Lockean economic message that rural lands like the Mara Triangle in Kenya must 'pay for themselves' has been devastating on Indigenous communities, as thousands of

\footnotetext{
${ }^{75}$ Note 72 above, at para. 53.

${ }^{76}$ Ibid., at para. 26.

${ }^{77}$ This is a key theme within TWAIL literature: Anghie in Anghie (2007).

${ }^{78}$ The tension here is also between modern ideas around conservation against colonially inherited modes of fortress conservation where forests need to be vacant spaces, conservation nullius, devoid of inhabitants for them to be pristine and saved. With thanks to Lucy Claridge for these insights.

${ }^{79}$ Hulme and Murphee (1999, p. 280).

${ }^{80}$ African Commission on Human and Peoples' Rights v. Republic of Kenya, Application no. 006/2012, at para. 8I (a).

${ }^{81}$ Note 41 above, at para. 165.
} 
hectares of prime wildlife habitat have been converted to wheat fields and Indigenous groups resettled in the process (Young, 2006, p. 324).

Starting in the 1980s, development agencies, through a large influx of budgets to conservation groups, rushed to put conservation into a developmental narrative such that conservation, biodiversity and development need not be antagonistic and could even be synergised. The above examples echo a kind of environmental nullius that might be used to continue a legal policy of terra nullius, to justify what Coulthard calls the ongoing imperialist 'double process' of civilisation and cultivation (Coulthard, 2014, p. 33). In Chagos, the environmental narratives on protectionism, climate change and development are used to justify the executive position on dispossession and thus prioritise political power. This creates a legal position in which Magna Carta protection is not extended to Chagossians through numerous policies discussed in this section, which Mance notes treat the BIOT as 'bare land', 82 as if the people inhabiting BIOT were an insignificant inconvenience, like the colonial void territories of terra nullius.

The evidence presented here illustrates how, in this case, the basic applicability of rights to abode are diluted and fragmented through several modes of neoliberal legal constructivism. These include policies giving legal support to the repetitive political use of domestic royal prerogative power without confirming legal precedent for exiling a settled population, legal and executive narratives that open the door for cynical environmental considerations as a means of diluting rights to return and a substantive weakening of the applicability of the doctrine of legitimate expectation in this case. Whilst no direct or causal 'connectivity' is suggested between these legal outcomes and the executive dialogue, it is of interest that the legal result and narrative have shown close favour with imperialist political and economic narrative, as the following further evidences.

\section{A judicial hardening of territoriality rules and effects on access to rights and justice}

On 11 December 2012, the European Court of Human Rights (ECHR) dismissed the application of the Chagossians in Chagos Islanders v. United Kingdom ${ }^{83}$ creating the astonishing position that international law and, crucially for this paper, relevant international human rights law relating to Chagossian rights to land and property do not apply to BIOT subjects.

Given the government's total control of BIOT, the applicants argued for its consideration as part of metropolitan UK, thus opening the door for Member State liability for activities undertaken outside its metropolitan area. The two territorial rules discussed were Article $1^{84}$ (the 'jurisdiction' clause) and the provisions under Article 56 on specialised territories ${ }^{85}$ (sometimes referred to as the 'colonial clause') of the European Convention. The argument extended on two separate fronts. First, that BIOT remained the same territory for whose foreign policy the UK was responsible and to which notification under Article 56 continued to apply after Mauritian independence, thus extending application of the UK Human Rights Act to BIOT subjects. Second, even if the government has not extended the Convention and right of individual petition to BIOT through formal notification after Mauritian independence, jurisdiction can still arise under grounds alternative to Article 56: Article $1 .{ }^{86}$ Article 1 jurisdiction applied, as the islands are completely constitutionally integrated into the UK such that British officials exercise authority and effective control over the BIOT area.

The ECHR rejected both arguments. At issue was the question of the relationship between these two provisions - specifically, whether Article 1's jurisdiction principle of 'effective control' might

\footnotetext{
${ }^{82}$ Note 21 above, at para. 157.

${ }^{83}$ Chagos Islanders, note 22 above.

${ }^{84}$ Article 1 provides 'the High Contracting Parties shall secure to everyone within their jurisdiction the rights and freedoms defined in Section 1 of this Convention', the key term being the interpretation of 'jurisdiction'.

${ }^{85}$ Article 56 provides 'Any state may at the time of its ratification or at any time thereafter declare by notification addressed to the Secretary General of the Council of Europe that the present Convention shall, subject to paragraph 4 of this Article, extend to all or any of the territories for whose international relations it is responsible'.

${ }^{86}$ Note 22 above, at paras 48,67 .
} 
provide legal satisfaction to claimants where no formal Article 56 declaration is made, as is the case for the Chagos Islands. In the earlier Al-Skeini case, ${ }^{87}$ the ECHR highlighted the separateness of the two legal regimes and 'the "effective control" principle of jurisdiction' required for Article 1, which does not replace and is 'clearly separate and distinct from' the 'system of declarations under Article 56 of the convention'. ${ }^{88}$ So, for Article 1 to apply, the level of control over a territory would have to be different from that which is normally the case in territories specifically covered by an Article 56 declaration (Frostad, 2013).

The jurisprudence on Article 1 and 56 applicability demonstrates a legal hardening of extraterritoriality rules. In Bui Van Thanh, ${ }^{89}$ the applicants claimed that, absent an Article 56 declaration, the acts of Hong Kong authorities were based on UK policy, thus triggering the jurisdiction of the UK for the purposes of Article 1. Rejecting the argument, the European Commission held that the mere fact that the acts of the Hong Kong authorities under Hong Kong immigration law were based on UK policy was insufficient to amount to an exercise of the latter's Article 1 'jurisdiction'. In Yonghong, ${ }^{90}$ a similar position was taken regarding the acts of the Portuguese Governor of Macau. Since Al-Skeini, the ECHR has concluded that extra-territorial responsibility remains exceptional and, in that case, highlighted the exceptional Iraqi 'security' circumstances of the cases before the Grand Chamber, where the United Kingdom had assumed 'authority and responsibility'. ${ }^{11}$

Chagos has reconfirmed that exceptional circumstances are required to trigger Article 1 responsibility. The threshold of control required in cases where no declaration has been made would be high, requiring, as Frostad (2013) opines, 'something close to an occupational authority', and thus seldom used apart from independence movements necessitating metropolitan military presence. This analysis aligns with leading rules requiring high levels of 'effective control' set down in Tadic ${ }^{92}$ for attributing state responsibility to internationally wrongful criminal acts of individuals or unorganised groups of individuals acting on behalf of a state. In that case, control required specific instructions or directives aimed at the commission of 'specific acts' and far more than a general level of control. Whether this onerous control test is fair and reasonable for the facts of the Chagos case is debatable.

On balance, the court's view in Chagos does not show any substantive departure from existing legal precedents on Article 1 applicability. However, it does suggest a judicial hardening on effective control levels for Article 1 application in cases where no Article 56 declaration has been made and a limiting of Article 56 responsibility solely to cases where declarations are expressly extended. In response to the applicants' contention that Article 56 should be set aside as an 'objectionable colonial relic', ${ }^{93}$ the ECHR retorted that, as 'anachronistic as colonial remnants may be, the meaning of article 56 ... cannot be ignored merely because of a perceived need to right an injustice', suggesting legal acquiescence in the ongoing 'colonial project'.

This dicta on justice is particularly disturbing when we consider exactly what legal rights Chagossians have been denied access to. Dis-application of human rights law has denied Chagossian communities access to applicable international human rights norms on land eviction and displacements, stripping them bare of useful human rights norms. Sociologist Cernea's seminal research on forced displacement from land enumerates the main impoverishment risks of

\footnotetext{
${ }^{87}$ Al-Skeini and Others v. United Kingdom, Application no. 55721/07, Council of Europe: European Court of Human Rights, 7 July 2011.

${ }^{88}$ Ibid., at para. 140 .

${ }^{89}$ Bui Van Than and Others v. the United Kingdom, Application no. 16137/90, 12 March 1990, Commission decision as to the admissibility, Vol. 65 European Commission of Human Rights Decisions July 1990 (1993).

${ }^{90}$ Yonghong v. Portugal, Application no. 50887/99, 25 November 1999, Decision as to the admissibility (English translation).

${ }^{91}$ Note 88 above, at para. 71, referring specifically to 'the maintenance of security in South East Iraq' and 'through its soldiers engaged in security operations in Basrah ... and had exercised authority and control over individuals killed during such security operations, to establish a jurisdictional link between the deceased and the United Kingdom for the purposes of Article 1 of the Convention'.

${ }^{92}$ Tadić, IT-94-1-A, International Criminal Tribunal for the former Yugoslavia (ICTY), 15 July 1999.

${ }^{93}$ Note 22 above, at para. 74.
} 
displacement as landlessness, joblessness, homelessness, marginalisation and food insecurity, loss of access to common property resources, increased morbidity and community dislocation (Cernea, 2003; Jeffery, 2011). Legal scholarship exploring how the judicial translation of the experience in terms of 'rights' and 'violations' appears rarely. Judicial pronouncements classify land displacement into hard violations of international human rights norms to property and possessions, ${ }^{94}$ privacy and family life, ${ }^{95}$ freedom of movement, ${ }^{96}$ non-discrimination ${ }^{97}$ and, in fewer cases, to an adequate standard of living including food ${ }^{98}$ and culture. ${ }^{99}$ Should Mauritius seek to honour these rights and, in so doing, pledge its commitment to honouring Chagossians' traditional land ties and the related human rights discussed above, it may provide a compelling argument in favour of Mauritian sovereignty within a UN system committed to dismantling the remanence of decolonisation, self-determination and ongoing colonialism.

\section{Concluding remarks}

I opened this paper with the following questions. How, despite the strong merits of the case, might we understand the decades-long exile of the Chagos Islanders and their inability to return to their ancestral land? What bearing might the international legal definition of 'Indigenous', human rights displacement case-law on land and the English law right to abode have on the Chagos Islanders' ability to return? Indeed, the rationale for the continued denial is the subject of ongoing debate amongst practitioners and academics who remain astonished by the legal record despite the ethical and moral merits of return. I have argued that Chagossian communities have strong legal rights to land and related remedies of compensation and return through a purposive application of the

\footnotetext{
${ }^{94}$ Dogan and Others v. Turkey, no. 8803-8811 1/02, 8813/02 and 8815-8819/02, ECHR 2004-VI, in which the ECHR ruled in favour of resettlement and damages to protect the customary property rights of villagers forcibly evicted by the Turkish government. Although villagers did not have registered property, the court accepted legal evidence of their traditional and unchallenged rights over the common lands in the village, such as the pasture, grazing and the forest land and informal landrelated customs demonstrating how villagers constructed houses on the lands of their ascendants or lived in the houses owned by their fathers and cultivated the land belonging to the latter. This evidence allowed the court to rule that those traditional land relations qualified as 'possessions' under Art. 1 of the European Convention.

${ }^{95}$ In eviction cases, Art. 8 violations of the European Convention were found in Dogan, note 94 above, Akdivar and Others v. Turkey, no. 21893/93, ECHR 1996, Selçuk and Asker v. Turkey, no. 23184/94, 23185/94, ECHR 1998-II, Bilgin v. Turkey, no. 23819/94, ECHR 2001, Dulas v. Turkey, no. 25801/94 ECHR 2001, Orhan v. Turkey, no. 25656/94, ECHR 2003, Ayder and others v. Turkey, no. 23656/94, ECHR 2004 and Legal Consequences of the Construction of a Wall Advisory Opinion, Judgment, ICJ Reports, 2004 in which the displacement of families caused by Israel's construction of the wall in the Occupied Palestinian Territory was a violation of the right to privacy, family and home under Art. 17 of the International Covenant on Civil and Political Rights (ICCPR).

${ }^{96}$ Malawi African Association and Others v. Mauritania, African Commission on Human and Peoples' Rights, Communication nos 54/91, 61/91, 98/93, 164/97, 196/97 and 210/98 (2000) involving the eviction of Black Mauritanians by the Moor community between 1986 and 1992 constituted a violation of their right to liberty of movement; DR Congo v. Burundi, Rwanda and Uganda, African Commission on Human and Peoples' Rights, Communication no. 227/99 (2003) the mass transfer of persons to camps in Rwanda was a breach of the right to freedom of movement and Legal Consequences of the Construction of a Wall, above, in which Israel's' construction of the wall resulted in violations of Palestinian's freedom of movement under Art. 12 of the ICCPR.

${ }^{97}$ Racial discrimination and its application to property through Art. 5 of the International Convention on the Elimination of all Forms of Racial Discrimination was used to overturn the colonial concept of 'terra nullius' or 'vacant' land as a discriminatory 'fiction by which the rights and interests of Indigenous inhabitants in land were treated as non-existent': see Mabo, note 42 above, at para. 42 , noting how 'a common law doctrine founded on unjust discrimination in the enjoyment of civil and political rights demands reconsideration'.

${ }^{98}$ Social and Economic Rights Action Centre for Economic and Social Rights v. Nigeria, Communication no. 155/96 (2001), in which Nigerian security forces' intentional destruction of the land and homes of Ogoni communities in the Niger Delta violated the minimum core of the right to food.

${ }^{99}$ For example, through the minority rights provisions in Art. 27 of the ICCPR. See Chief Bernard Ominayak and Lubicon Lake Band v. Canada [1990] CCPR/C/38/D/167/1984, UN Human Rights Committee, recognised that the rights protected by Art. 27 include the right of persons, in community with others, to engage in economic and social activities that are part of the culture of the community to which they belong.
} 
international legal definition of Indigenous, English Magna Carta right to abode and international human rights law that could address their continued expulsion. My argument is novel, as I suggest that the inability of those rights to be meaningfully applied to the Chagossians has been constrained because of the strict post-colonial way those rights are legally interpreted and the imperialist thinking underpinning the parochial application and dis-application of those rights, creating a legal vacuum in which basic fairness and substantive equality are and can be routinely compromised. My overall aim in this piece is to draw attention to the post-colonial narratives behind the denial of return in the Chagos case and to 'push the envelope' towards the purposive development of concepts such as Indigenous people in eviction cases like Chagos. After all, without zeal, foresight and some bold thinking, who would have imagined that a crime like genocide could take shape in such a short space of time. In this vein, I hope to provide an alternative and fresh perspective on the case for those concerned with the plight of the Chagos Islanders.

Acknowledgements. This paper would not have been possible without the support of several interlocutors and organisations that took the time to speak with me. I would like to thank lawyers at Human Rights Watch and Minority Rights Group International. Special thanks to the Chagossians living in Croydon and Crawley who, during the summer of 2015, took time to talk openly with me about their social and legal experiences of eviction. I also thank the UK Chagos Support Association for giving me the opportunity to sit as Vice-Chair of the group during which time I have had the honour of discussing the political, social and legal aspects of the case with community members and of attending the October 2015 All Party Parliamentary Group debate on the Chagos Islands in Westminster.

\section{References}

Allen S (2007) Looking beyond the Bancoult cases: international law and the prospect of resettling the Chagos Islands. Human Rights Law Review 7, 441-482.

Allen S (2014) Chagos Islanders and International Law. Oxford: Hart Publishing.

Anghie A (2007) Imperialism, Sovereignty and the Making of International Law. Cambridge, UK/New York: Cambridge University Press.

Bingham TH (2010) The Rule of Law. London: Penguin.

Boycott O (2017) EU members abstain as Britain defeated in UN vote on Chagos Islands, The Guardian, 23 June 2017. Available at https://www.theguardian.com/world/2017/jun/22/un-vote-backing-chagos-islands-a-blow-for-uk (accessed 12 March 2018).

Cernea M (2003) For a new economics of resettlement: a sociological critique of the compensation principle. International Social Science Journal 175, 37-45.

Coulthard GS (2014) Red Skin, White Masks. Minneapolis: University of Minnesota Press.

Dworkin R (1985) A Matter of Principle. Cambridge, MA: Harvard University Press.

Fanon F (1967) The Wretched of the Earth. Harmondsworth: Penguin.

Flanagan T (1989) The agricultural argument and original appropriation: Indian lands and political philosophy. Canadian Journal of Political Science 22: 589-602.

Frostad M (2013) The 'colonial clause' and extraterritorial application of human rights: the European Convention on Human Rights Article 56 and its relationship to Article 1. Arctic Review on Law and Politics 4, 21-41.

Gilbert J (2007) Nomadic territories: a human rights approach to nomadic peoples' land rights. Human Rights Law Review 7 , 681-716.

Huh S (2015) Title to territory in the post-colonial era: original title and terra nullius in the ICJ judgments on cases concerning Ligitan/Sipadan (2002) and Pedra Branca (2008). European Journal of International Law 26, 709-725.

Hulme D and Murphree M (1999) Policy arena: communities, wildlife and the 'new conservation' in Africa. Journal of International Development 2, 277-285.

Jeffery L (2011) Chagos Islanders in Mauritius and the UK Forced Displacement and Onward Migration. New Ethnographies. Manchester: Manchester University Press.

Jones S and Motha S (2015) A new nomos offshore and bodies as their own signs. Law \& Literature 27, 253-278.

Kingsbury B (1998) Indigenous peoples' in international law: a constructivist approach to the Asian controversy. American Journal of International Law 92, 414-457.

Kymlicka W (1995) Multicultural Citizenship: A Liberal Theory of Minority Rights. Oxford: Clarendon Press.

Laslett P (1960) Locke's Two Treatises of Government, 2nd edn. Cambridge: Cambridge University Press.

Martínez Cobo J (1986/7) Study of the problem of discrimination against Indigenous populations', UN Doc. E/CN.4/Sub.2/ 1986/7. Available at http://www.un.org/esa/socdev/unpfii/documents/MCS_xvii_en.pdf (accessed 26 June 2017). 
Mutua M and Anghie A (2000) What is TWAIL? Proceedings of the Annual Meeting (American Society of International Law) 94: 31-40.

O'Connell P (2011) The death of socio-economic rights. Modern Law Review 74, 532-554.

Poole T (2010) United Kingdom: the royal prerogative. International Journal of Constitutional Law 8, 146-155.

Povinelli E (2011) The governance of the prior. Interventions 13, 13-30.

Prasad P (2009) Colonialism, Race, and the French Romantic Imagination. London: Routledge.

Sassen S (2014) Expulsions: Brutality and Complexity in the Global Economy. Cambridge: Harvard University Press.

Waldron J (2003) Indigeneity? First peoples and last occupancy. New Zealand Journal of Public and International Law 1, 55-82.

Wiessner S (2011) The cultural rights of Indigenous peoples: achievements and continuing challenges. European Journal of International Law 22, 121-140.

Wolfe P (2006) Settler colonialism and the elimination of the native. Journal of Genocide Research 8, 387-409.

Young T (2006) Declining rural populations and the future of biodiversity: missing the forest for the trees? Journal of International Wildlife Law and Policy 9, 319-334.

Cite this article: Bhatt K (2019). A post-colonial legal approach to the Chagos case and the (dis)application of land rights norms. International Journal of Law in Context 15, 1-19. https://doi.org/10.1017/S1744552318000095 